\title{
Anti-cancer and anti-hepatitis C virus NS5B polymerase activity of etodolac 1,2,4-triazoles
}

\section{Pelin Çıkla-Süzgün, Neerja Kaushik-Basu, Amartya Basu, Payal Arora, Tanaji T. Talele, Irem Durmaz, Rengül Çetin-Atalay \& Ş.Güniz Küçükgüzel}

To cite this article: Pelin Çıkla-Süzgün, Neerja Kaushik-Basu, Amartya Basu, Payal Arora, Tanaji T. Talele, Irem Durmaz, Rengül Çetin-Atalay \& Ș.Güniz Küçükgüzel (2015) Anti-cancer and antihepatitis $\mathrm{C}$ virus NS5B polymerase activity of etodolac 1,2,4-triazoles, Journal of Enzyme Inhibition and Medicinal Chemistry, 30:5, 778-785, DOI: 10.3109/14756366.2014.971780

To link to this article: http://dx.doi.org/10.3109/14756366.2014.971780

View supplementary material ¿

曲 Published online: 27 Aug 2015.

Submit your article to this journal

III Article views: 231

Q View related articles $\longleftarrow$

$($ View Crossmark data

4 Citing articles: 4 View citing articles ¿ 


\title{
Anti-cancer and anti-hepatitis C virus NS5B polymerase activity of etodolac 1,2,4-triazoles*
}

\author{
Pelin Çıkla-Süzgün ${ }^{1}$, Neerja Kaushik-Basu², Amartya Basu² ${ }^{2}$ Payal Arora² ${ }^{2}$ Tanaji T. Talele ${ }^{3}$, Irem Durmaz ${ }^{4}$, \\ Rengül Çetin-Atalay ${ }^{4}$, and Ş.Güniz Küçükgüzel ${ }^{1}$
}

\begin{abstract}
${ }^{1}$ Department of Pharmaceutical Chemistry, Faculty of Pharmacy, Marmara University, Istanbul, Turkey, ${ }^{2}$ Department of Biochemistry and Molecular Biology, New Jersey Medical School, Rutgers, The State University of New Jersey, New Jersey, NJ, USA, ${ }^{3}$ Department of Pharmaceutical Sciences, College of Pharmacy and Health Sciences, St. John's University, Queens, NY, USA, and ${ }^{4}$ Department of Molecular Biology and Genetics, Bilkent University, Ankara, Turkey
\end{abstract}

\begin{abstract}
Arachidonic acid is an unsaturated fatty acid liberated from phospholipids of cell membranes. NSAIDs are known as targets of cyclooxygenase enzyme (COX-1, COX-2 and COX-3) in arachidonic acid metabolism. This mechanism of COX-2 in carcinogenesis causes cancer. In addition, COX-2 plays a role in the early stages of hepatocarcinogenesis. Hepatitis $\mathrm{C}$ virus (HCV) infection is cause of liver cirrhosis and hepatocellular carcinoma (HCC). The aim of our study was to improve effective agents against HCV. A novel series of new etodolac 1,2,4-triazoles derivatives (4a-h) have been synthesized and investigated for their activity against HCV NS5B polymerase. Compound $4 \mathrm{a}$ was found to be the most active with $\mathrm{IC}_{50}$ value of $14.8 \mu \mathrm{M}$. In accordance with these results, compound $\mathbf{4 a}$ was screened for anti-cancer activity on liver cancer cell lines (Huh7, Mahlavu, HepG2, FOCUS). Compound 4a showed anti-cancer activity against Huh7 human hepatoma cell line with $I_{50}$ value of $4.29 \mu \mathrm{M}$. Therefore, compound $4 \mathrm{a}$ could be considered as a new anti-cancer and anti-HCV lead compound.
\end{abstract}

\section{Keywords}

1,2,4-Triazole-3-thione, etodolac, HCV NS5B polymerase, hepatocellular carcinoma

\section{History}

Received 4 July 2014

Revised 26 September 2014

Accepted 29 September 2014

Published online 13 February 2015

\section{Introduction}

Non-steroidal anti-inflammatory drugs (NSAIDs) have recently gained attention as promising cancer chemopreventive agents. Evidence for a connection between COX-2 activation and carcinogenesis has come from a number of studies ${ }^{1}$. In addition, many epidemiological studies have also highlighted COX-2 as an important molecular target for anti-cancer therapy. Overexpression of COX-2 in tumor cell lines affect diverse mechanisms involved in carcinogenesis, such as angiogenesis, inhibition of apoptosis, stimulation of cell growth as well as the invasiveness of tumor cells. Hepatocellular carcinoma (HCC) is one of the most common cancers worldwide, accounting for approximately 1 million deaths annually and an estimated 500000 new cases per year ${ }^{2}$. Most cases of HCC are secondary to either viral hepatitis infection (hepatitis B or C) or cirrhosis ${ }^{3}$. High levels of COX-2 expression in hepatocytes may be involved in

\footnotetext{
*This work was partly presented at the 2nd International BAU-Drug Design Congress, Nowel Methods and Emerging Targets in Drug Design\&Patented Drug Development, Istanbul-TURKEY, 17-19 April 2014.

Address for Correspondence: Ş. Güniz Küçükgüzel, Department of Pharmaceutical Chemistry, Faculty of Pharmacy, Marmara University, Haydarpaşa, 34668 İstanbul, Turkey. Fax: +90-216-3452952. E-mail: gkucukguzel@marmara.edu.tr
}

hepatocarcinogenesis following $\mathrm{HBV}$ and $\mathrm{HCV}$ infections. COX-2 upregulation has also been correlated with the presence of inflammatory cells in hepatocarcinogenesis and tumor angiogenesis in $\mathrm{HCC}^{4}$. COX-2 inhibitors have displayed significant antiproliferative effects in many human HCC cell lines ${ }^{5}$. Further, investigations on animal models of liver cancer have shown that NSAIDs, including selective COX-2 inhibitors, exhibit chemopreventive as well as therapeutic effects. Etodolac, $(R, S)-2-[1,8-$ diethyl-1,3,4-tetrahydrapyrano[3,4-b]indole-1-yl]acetic acid, is a nonsteroidal antiinflammatory drug with marked antirheumatic, analgesic and antipyretic properties. It exists as a racemic mixture of $R$ - and $S$-enantiomers that are not metabolically interconvertible, of which the the $S$-enantiomer exhibits selective COX-2 inhibitory activity ${ }^{6}$. Etodolac, at physiological doses has been reported to decrease the cell proliferative effect of $\beta$-catenin in hepatoma cells ${ }^{7}$ and also decrease PGE2 levels in HCV-associated $\mathrm{HCC}^{8}$. Other studies have reported the anti-HCC properties of etodolac through mechanisms involving growth inhibition and cell cycle arrest ${ }^{9}$. Thus, etodolac appears to be a promising scaffold for the development of novel anti-hepatitis $\mathrm{C}$ and anti-HCC agents.

Among other anti-tumor and anti-HCVagents, the 1,2,4triazoles and pyrano[3,4-b]indoles bearing compounds have displayed promising characteristics. The five-membered heterocyclic ring of the triazoles has served as an important scaffold for many bioactive compounds, some of which have emerged as effective and non-toxic antitumor drugs ${ }^{10,11}$. The pyrano[3,4-b]indole 
derivatives, on the other hand, have been documented as potent in vitro anti-HCV NS5B polymerase inhibitor ${ }^{12,13}$. We recently reported on the synthesis of etodolac thiosemicarbazides and identified their anti-HCV NS5B polymerase activity $^{14}$.

In continuation of our efforts towards developing new anticancer agents with enhanced biological properties and potent antiHCV NS5B polymerase activity, here we report on the synthesis and biological evaluation of novel etodolac 1,2,4-triazole derivatives. A total of 34 etodolac hydrazide derivatives were investigated for their activity against HCV NS5B polymerase. Selected compounds were evaluated for anti-cancer activity against a panel of 60 human tumor cell lines in addition to four hepatocellular cell lines We further report on the potential binding mode of the most active etodolac 1,2,4-triazole derivative on NS5B.

\section{Experimental}

\section{Chemistry}

\section{General}

All chemicals were purchased from Merck Co. (Darmstadt, Germany), Sigma-Aldrich (St. Louis, MO) or Fluka (Buchs, Switzerland). Reactions were monitored by thin-layer chromatography (TLC) on aluminium oxide 60F254 plates (Merck Co., Darmstadt, Germany). Melting points of the synthesized compounds were determined in Schmelzpunktgerät SMP II melting point apparatus and are presented without any corrections. The purity of the compounds was checked on TLC plates precoated with silica gel $\mathrm{G}$ in a solvent system comprising of petroleum ether: ethyl acetate (50:50, v/v) mixture as an eluent. The spots were located under UV light $(254 \mathrm{~nm})\left(t: 21^{\circ} \mathrm{C}\right)$. FT-IR spectra were recorded on Shimadzu FTIR-8400S spectrophotometer. NMR spectra were recorded on BRUKER AVANCE-DPX 400 at $400 \mathrm{MHz}$ and Bruker 300 at $300 \mathrm{MHz}$ (Billerica, MA) for ${ }^{1} \mathrm{H}-$ NMR and $75 \mathrm{MHz}$ for ${ }^{13} \mathrm{C}-\mathrm{NMR}$ (Decoupled). The chemical shifts $(\delta)$ were expressed in parts per million (ppm) downfield from tetramethylsilane (TMS) using DMSO- $\mathrm{d}_{6}$ as solvent. Data are reported as follows: chemical shift, multiplicity (b.s.: broad singlet, d: dublet; $\mathrm{m}$ : multiplet, $\mathrm{s}$ : singlet, and $\mathrm{t}$ : triplet), coupling constants $(\mathrm{Hz})$, integration. MALDI-TOF HR-MS spectra using EI and FAB ionization techniques were performed using a Jeol JMS-700 instrument.

Synthesis of methyl (1,8-diethyl-1,3,4,9-tetrahydropyrano[3,4b]indole-1-yl) acetate 1, 2-(1,8-diethyl-1,3,4,9-tetrahydropyrano[3,4-b]indole-1-yl)acetohydrazide 2, and 1-[2-(1,8-diethyl1,3,4,9-tetrahydropyrano[3,4-b]indole-1-yl)acetyl]-4-alkyl/aryl thiosemicarbazides (3a-h)

These etodolac derivatives were designed and prepared as described previously in our studies ${ }^{14-16}$.

General procedure for the synthesis 5-[(1,8-diethyl-1,3,4,9tetrahydropyrano[3,4-b]indole-1-yl)methyl]-4-substituted-2,4dihydro-3H-1,2,4-triazole-3-thiones $(\mathbf{4 a}-\boldsymbol{h})$

A solution of $0.01 \mathrm{~mol}(\mathbf{3 a}-\mathbf{h})$ in sodium hydroxide solution $(25 \mathrm{~mL})$ was heated under reflux for $4 \mathrm{~h}$. After cooling to room temperature, the solution was adjusted to $\mathrm{pH} 6$ by concentrated hydrochloric acid. The crude product was precipitated, filtered and washed with distilled water. Pure compounds were obtained by recrystallization from ethanol.

The following compounds were prepared by an analogous procedure. The characterization of compounds $4 \mathbf{b}-\mathbf{e}, \mathbf{4 g}-\mathbf{h}$ could be seen in Supplemental file 1.
5-[(1,8-Diethyl-1,3,4,9-tetrahydropyrano[3,4-b]indole-1-yl) methyl]-4-methyl-2,4-dihydro-3H-1,2,4-triazole-3-thione

(4a). Light cream-colored solid. Yield 71\%; m.p. 227-229 ${ }^{\circ}$; MW: $356.485 ; R_{f} \times 100$ value: 46.77 . FT-IR $\left(\nu_{\max }, \mathrm{cm}^{-1}\right): 3279$ (indole and triazole $\mathrm{NH}) ; 1562,1470,1464,1456(\mathrm{C}=\mathrm{N}, \mathrm{C}=\mathrm{C})$; $1239(\mathrm{C}=\mathrm{S}) .{ }^{1} \mathrm{H}$ NMR $\left(400 \mathrm{MHz}, \mathrm{DMSO}-\mathrm{d}_{6}\right) \delta \mathrm{ppm}: 0.64(\mathrm{t}, 3 \mathrm{H}$, $-\mathrm{CH}_{2}-\mathrm{CH}_{3}$ at $\left.\mathrm{C}_{1}\right) ; 1.27\left(\mathrm{t}, 3 \mathrm{H},-\mathrm{CH}_{2}-\mathrm{CH}_{3}\right.$ at $\left.\mathrm{C}_{8}\right) ; 1.67-2.09(\mathrm{~m}$, $2 \mathrm{H},-\mathrm{CH}_{2}-\mathrm{CH}_{3}$ at $\left.\mathrm{C}_{1}\right) ; 2.57-2.89\left(\mathrm{~m}, 4 \mathrm{H},-\mathrm{CH}_{2}\right.$ at $\mathrm{C}_{1}$ and $-\mathrm{CH}_{2}-$ $\mathrm{CH}_{3}$ at $\left.\overline{\mathrm{C}}_{8}\right) ; 3.30-3.46\left(\mathrm{~m}, 5 \mathrm{H},-\mathrm{CH}_{2}\right.$ at $\left.\mathrm{C}_{4} \overrightarrow{\text { and }} \mathrm{N}-\mathrm{CH}_{3}\right) ; 3 . \overline{85}-$ $3.97\left(\mathrm{~m}, 2 \mathrm{H},-\mathrm{CH}_{2}\right.$ at $\left.\mathrm{C}_{3}\right) ; 6.89-7.24(\mathrm{~m}, 3 \mathrm{H}, \mathrm{Ar}-\mathrm{H}) ; 10.67(\mathrm{~s}, 1 \mathrm{H}$, indole $\mathrm{NH}) ; 13.49(\mathrm{~s}, 1 \mathrm{H}$, triazole $\mathrm{NH}) .{ }^{13} \mathrm{C} \mathrm{NMR}(100 \mathrm{MHz}$, DMSO-d $\left.{ }_{6} / \mathrm{TMS}\right) \delta$ ppm: 8.15 (C-12); 15.02 (C-10); 22.32 (C-4); 24.26 (C-9); 31.13 (C-11); $31.48\left(\mathrm{~N}-\mathrm{CH}_{3}\right) ; 34.09$ (C-13); 60.85 (C-3); 77.10 (C-1); 108.50 (C-5); 115.94 (C-1a); 119.26 (C-6); 120.30 (C-7); 126.32 (C-8a); 127.14 (C-8); 135.11 (C-5a); 135.63 $(\mathrm{C}-4 \mathrm{a}) ; 150.04($ triazol $-\mathrm{C}=\mathrm{N}) ; 169.90(\mathrm{C}=\mathrm{S}) . \mathrm{HR}-\mathrm{MS}\left(\mathrm{EI}^{+}\right)$ Calculated/Found $\quad(\mathrm{m} / \mathrm{z}): \quad 356.1670 / 356.1663 \quad\left(\mathrm{M}^{+}\right)$ $\left(\mathrm{C}_{19} \mathrm{H}_{24} \mathrm{~N}_{4} \mathrm{OS}\right) ; \quad 324.1950 / 324.1943 \quad\left(\mathrm{C}_{19} \mathrm{H}_{24} \mathrm{~N}_{4} \mathrm{O}\right) ; 281.1581 /$ $281.1633 ; 279.1372 / 279.1453 ; 268.1576 / 268.1513 ; 243.1623 /$ $243.1576 ; 229.1466 / 229.1409 ; 228.1382 / 228.1345\left(\mathrm{C}_{15} \mathrm{H}_{18} \mathrm{NO}\right)$; $227.1310 / 227.1298$.

\section{5-[(1,8-Diethyl-1,3,4,9-tetrahydropyrano[3,4-b]indole-1-yl)} methyl]-4-benzyl-2,4-dihydro-3H-1,2,4-triazole-3-thione

(4f). Light cream-colored solid. Yield 50\%; m.p. $163-166^{\circ} \mathrm{C}$; MW: $432.581 ; R_{f} \times 100$ value: 80.60 . FT-IR $\left(\nu_{\max }, \mathrm{cm}^{-1}\right): 3270$ (indole and triazole $\mathrm{NH}) ; 1574,1497,1453,1418(\mathrm{C}=\mathrm{N}, \mathrm{C}=\mathrm{C})$; $1261(\mathrm{C}=\mathrm{S}) .{ }^{1} \mathrm{H}$ NMR $\left(400 \mathrm{MHz}, \mathrm{DMSO}-\mathrm{d}_{6}\right) \delta \mathrm{ppm}: 0.67(\mathrm{t}, 3 \mathrm{H}$, $-\mathrm{CH}_{2}-\mathrm{CH}_{3}$ at $\left.\mathrm{C}_{1}\right) ; 1.26\left(\mathrm{t}, 3 \mathrm{H},-\mathrm{CH}_{2}-\mathrm{CH}_{3}\right.$ at $\left.\mathrm{C}_{8}\right) ; 1.81-2.05(\mathrm{~m}$, $2 \mathrm{H},-\mathrm{CH}_{2}-\mathrm{CH}_{3}$ at $\left.\mathrm{C}_{1}\right) ; 2.82-3.35\left(\mathrm{~m}, 6 \mathrm{H},-\mathrm{CH}_{2}-\mathrm{CH}_{3}\right.$ at $\mathrm{C}_{8}$, $-\mathrm{CH}_{2}-$ at $\mathrm{C}_{1}$ and $-\mathrm{CH}_{2}$ at $\left.\mathrm{C}_{4}\right) ; 3.60-3.88\left(\mathrm{~m}, 2 \overline{\mathrm{H}},-\mathrm{CH}_{2}\right.$ at $\left.\mathrm{C}_{3}\right)$; 5.21-5.32 (m, 2H, N-CH $)$; 6.89-7.36 (m, 8H, Ar-H); 10.62 (s, $1 \mathrm{H}$, indole $\mathrm{NH}) ; 13.67(\mathrm{~s}, 1 \mathrm{H}$, triazole $\mathrm{NH}) .{ }^{13} \mathrm{C} \mathrm{NMR}(100 \mathrm{MHz}$, DMSO-d $\left.{ }_{6} / \mathrm{TMS}\right) \delta$ ppm: 8.18 (C-12); 14.94 (C-10); 22.26 (C-4); 24.24 (C-9); 31.39 (C-11); 34.35 (C-13); $46.22\left(\mathrm{~N}-\mathrm{CH}_{2}\right) ; 60.89$ (C-3); 77.13 (C-1); 108.37 (C-5); 115.99 (C-1a); 119.28 (C-6); 120.31 (C-7); $126.28\left(\mathrm{C}^{\prime}\right) ; 127.11\left(\mathrm{C}^{\prime}\right.$ and $\left.\mathrm{C}^{\prime}\right) ; 128.05\left(\mathrm{C}^{\prime}\right.$ and $\left.\mathrm{C}^{\prime}\right)$; 129.15 (C-8 and C-8a); 135.09 (C-5a); 135.53 (C4a); $136.32\left(\mathrm{Cl}^{\prime}\right) ; 149.64 \quad($ triazol $-\mathrm{C}=\mathrm{N}) ; 167.46 \quad(\mathrm{C}=\mathrm{S})$. HR-MS $\left(\mathrm{EI}^{+}\right)$Calculated/Found $(\mathrm{m} / \mathrm{z}): 432.1983 / 432.1975\left(\mathrm{M}^{+}\right)$ $\left(\mathrm{C}_{25} \mathrm{H}_{28} \mathrm{~N}_{4} \mathrm{OS}\right) ; \quad 229.1466 / 229.1417 ; \quad 228.1382 / 228.1385$ $\left(\mathrm{C}_{15} \mathrm{H}_{18} \mathrm{NO}\right) ; 227.1310 / 227.1302$.

\section{Materials and methods}

\section{Anti-cancer activity}

Compounds $\mathbf{4 b}$ and $\mathbf{4 f}$ were chosen as prototypes for anti-cancer evaluations at the National Institute of Health-National Cancer Institute (NIH-NCI). Growth inhibition was evaluated against a panel of 60 human tumor cell lines derived from nine neoplastic diseases (leukaemia, non-small cell lung cancer (NSCL), colon cancer, central nervous system (CNS) cancer, melanoma, ovarian cancer, renal cancer, prostate cancer and breast cancer cell lines) at 10-fold dilutionsin a primary anti-cancer assay in accordance with the protocol of the Drug Evaluation Branch, NCI, Bethesda $^{17-19}$.

Briefly, the tumor cell lines were seeded in 96-well microtiter plates in RPMI 1640 medium containing 5\% fetal bovine serum and $2 \mathrm{mM} \mathrm{L}$-glutamine at $37^{\circ} \mathrm{C}, 5 \% \mathrm{CO}_{2}, 95 \%$ air and $100 \%$ relative humidity atmosphere for $24 \mathrm{~h}^{19}$. Compounds were screened at a single concentration of $10^{-5} \mathrm{M}$ for $48 \mathrm{~h}$ and growth inhibition was investigated by the sulforhodamine $\mathrm{B}$ (SRB) protein assay ${ }^{17}$. The $50 \%$ inhibition was extrapolated from dose-response parameters at 10 -fold dilutions of compounds as described previously ${ }^{18}$. The percentage of growth inhibition was 
determined spectrophotometrically against DMSO treated controls.

\section{HCV NS5B polymerase inhibitory activity}

The effect of the compounds on HCV NS5B polymerase activity was evaluated on poly $\mathrm{rA}-\mathrm{U}_{12}$ template- primer in the presence of $\left[\alpha^{32} \mathrm{P}\right]$ UTP and $\mathrm{MnCl}_{2}$ as the divlent cation as described previously ${ }^{20,21}$. Reactions in the presence of the compound or DMSO were incubated at $30^{\circ} \mathrm{C}$ for $1 \mathrm{~h}$ and terminated by the addition of 5\% TCA. The nascent radiolabeled RNA was precipitated on GF-B filters and counted in a liquid scintillation counter. NS5B activity in the presence of DMSO was set at 100\% and that in the presence of the compounds was determined relative to this control. Preliminary screning was conducted at $100 \mu \mathrm{M}$ compound concetration and those exhibiting $\geq 50 \%$ inhibition were investigated further for their $\mathrm{IC}_{50}$ values at 8-10 concentrations of the serially diluted compounds. The $\mathrm{IC}_{50}$ values were analyzed from dose-response curves utilizing Graphpad prism 3.03 software (La Jolla, CA).

\section{Molecular modeling}

The X-ray co-crystal structure of HCV NS5B-PF868554 (PDB ID: 3FRZ) obtained from the RCSB Protein Data Bank (Piscataway, NJ) was used for docking the compounds into the NS5B thumb pocket-II ${ }^{22}$. The protein structure was processed by means of default parameters mentioned in Protein Preparation Tool present in Maestro v9.0 and Impact program v5.5 (Schrödinger, Inc., New York, NY), in which the protonation states of residues were adjusted to the dominant ionic forms at $\mathrm{pH}$ 7.4. Refined HCV NS5B structure was further used to generate energy grid by selecting bound inhibitor (PF868554) as a reference ligand.

\section{Docking protocol}

Compounds were constructed using the fragment dictionary of Maestro 9.0 and energy minimized by Macromodel program v9.7 (Schrödinger, Inc., New York, NY). The energy minimization involved steepest descent followed by truncated Newton conjugate gradient application of OPLSAA force field parameters (convergence criteria of $0.001 \mathrm{rmsd}$ was used). The low-energy 3D structures of etodolac analogs were generated with the help of LigPrep v2.3 (Schrödinger Inc., New York, NY): different protonation states at physiological $\mathrm{pH}$, all possible tautomers, ring conformations and stereoisomers ${ }^{23}$. The resulting LigPrep derived structures were used for docking simulations. The X-ray co-crystal structure of HCV NS5B-PF868554 (PDB ID: 3FRZ) was used for docking into thumb pocket-II ${ }^{22}$. Protein refinement without crystallographic water molecules, energy grid generation using bound ligand as a reference, and "Extra Precision" (XP) Glide docking v5.0 (Schrödinger, Inc., New York, NY) was performed with the default parameters. The top scoring pose of compound $\mathbf{4 a}$ within the TP-II was used for graphical analysis. All computations were carried out on a Dell Precision $470 \mathrm{n}$ dual processor with the Linux OS (Red Hat Enterprise WS 4.0, Raleigh, NC).

\section{NCl-Sulforhodamine B (SRB) anti-cancer assay of etodolac triazole, SGK-238 on human liver cancer cells}

Human liver cancer cells (Huh7, Mahlavu, HepG2, FOCUS) were cultured in 96-well plates (1000-3000 cell/well) and grown for $24 \mathrm{~h}$. Then the cells were treated with increasing concentrations of the compound $(2.5-40 \mu \mathrm{M})$. After $72 \mathrm{~h}$ treatment, the growth medium was aspirated and cells were washed with $1 \times \mathrm{PBS}$ $\left(\mathrm{CaCl}_{2}-, \mathrm{MgCl}_{2}\right.$-free) (Gibco, Invitrogen, Grand Island, NY) followed by the addition of $50 \mu \mathrm{l}$ cold $10 \%(\mathrm{v} / \mathrm{v})$ trichloroacetic acid (TCA) and incubated $1 \mathrm{~h}$ at $4^{\circ} \mathrm{C}$. TCA solution was then aspirated and the micro-plates were washed five times with deionized water and left air-dry. Finally, $50 \mu \mathrm{l}$ of $0.4 \%(\mathrm{~m} / \mathrm{v})$ sulforhodamine (Sigma-Aldrich) in 1\% acetic acid solution was added to each well and the plates were incubated for $10 \mathrm{~min}$ at room temperature. In order to remove the unbound stain, the plates were washed five times with $1 \%$ acetic acid and left to airdry. The bound sulforhodamine B was then solubilized using $10 \mathrm{mM}$ Tris-base. The absorbance was measured at $515 \mathrm{~nm}$.

\section{Results and discussion}

\section{Chemistry}

$(R, S)$-2-[1,8-Diethyl-1,3,4-tetrahydrapyrano[3,4-b]indole-1-yl]acetic acid (etodolac) was chosen as the starting compound to design 1,2,4-triazole-3-thiones derivatives. Synthesis of triazole derivatives $(\mathbf{4 a}-\mathbf{h})$ required stepwise reactions starting with etodolac hydrazide. The synthetic route for the title compounds is shown in Figure 1. In our previous study, we synthesized methyl 2-(1,8-diethyl-1,3,4,9-tetrahydropyrano[3,4-b]indole-1-yl) acetate (1) and 2-(1,8-diethyl-1,3,4,9-tetrahydropyrano[3,4$b$ ]indole-1-yl)acetohydrazide (2) ${ }^{15}$. The reaction of corresponding hydrazide 2 with respective alkyl/aryl isothiocyanates yielded etodolac thiosemicarbazides $(\mathbf{3 a}-\mathbf{h})^{14,16}$. In present study, smooth cyclization of etodolac thiosemicarbazides under alkaline conditions afforded the 5-[(1,8-diethyl-1,3,4,9-tetrahydropyrano[3,4-b] indole-1-yl)methyl]-4-substituted-2,4-dihydro-3H-1,2,4-triazole3 -thiones $(\mathbf{4 a}-\mathbf{h})$ in moderate to good yields ${ }^{16}$. These compounds are original. All the newly synthesized etodolac 1,2,4-triazoles are air-stable solids and soluble in DMSO at ambient temperature. The purity of the synthesized compounds was checked by thin layer chromatography (TLC) and microanalysis. The structures of obtained compounds were determined on the basis of FT-IR, ${ }^{1} \mathrm{H}-$ NMR, ${ }^{13} \mathrm{C}-\mathrm{NMR}$ and HR-MS spectral data and all of the compounds have satisfactory analyses for their proposed structures. ${ }^{1} \mathrm{H}$-NMR soctral results for etodolac triazoles together with hydrogen assignments. ${ }^{13} \mathrm{C}-\mathrm{NMR}$ and HR-MS spectra results are also demonstrated in Experimental Section.

The refluxing of etodolac thiosemicarbazides in aqueous $\mathrm{NaOH}$ transformed into the target compounds $(\mathbf{4 a}-\mathbf{h})$ was indicated in the IR spectra by appearance of a single absorption for $\mathrm{NH}$ in the region $3160-3349 \mathrm{~cm}^{-1}$ and disapperance of a comparatively strong band in the region $1674-1688 \mathrm{~cm}^{-1}$ for the carbonyl of hydrazides, indicated the formation of triazoles. The absorption bands at $1576-1416 \mathrm{~cm}^{-1}$ are due to the presence of $-\mathrm{C}=\mathrm{N}-$ stretch of the triazole ring system. Furthermore, the appearance of a $\mathrm{C}=\mathrm{S}$ absorption band in the region 1215$1262 \mathrm{~cm}^{-1}$ indicated that the triazoles are in their thione form. The existence of triazoles in thione form was also indicated by the absence of SH stretching in the characteristic region of 2550 $2600 \mathrm{~cm}^{-124}$.

${ }^{1} \mathrm{H}-\mathrm{NMR}$ data was also in agreement with the proposed structures of all newly synthesized etodolac triazoles. Moreover, in the ${ }^{1} \mathrm{H}-\mathrm{NMR}$ spectra of etodolac triazoles, additional signals due to the $\mathrm{NH}$ group were appeared in the region of $\delta 13.38$ $13.82 \mathrm{ppm}$, whereas $\mathrm{S}-\mathrm{H}$ proton at $1.0-3.7 \mathrm{ppm}$ was not detected which also confirmed the formation of their thionic form ${ }^{25}$. Triazole NH resonances were observed to be shifted to downfield because of strong intermolecular hydrogen bonding as previously reported ${ }^{26,27} .{ }^{1} \mathrm{H}-\mathrm{NMR}$ spectra of the etodolac thiosemicarbezides (3a-h) showed three proton signals typical for linked to $\mathrm{N}^{1}-\mathrm{N}^{2}$ and $\mathrm{N}^{4}$ nitrogens in the 7.03-10.55 ppm range in our previous study, whereas in the ${ }^{1} \mathrm{H}-\mathrm{NMR}$ spectra of etodolac triazoles $(\mathbf{4} \mathbf{a}-\mathbf{h})$ the singlet peak due to the proton of $\mathrm{NH}$ group appeared, which confirmed the succesful formation of the desired triazoles. All 
<smiles>CCc1cccc2c3c([nH]c12)C(CC)(CC(=O)O)OCC3</smiles>

Etodolac<smiles>CCc1cc(N)cc2c3c([nH]c12)C(CC)(CC(=O)NN)OCC3</smiles>

$\mathrm{R}(\mathrm{Ar})-\mathrm{NCS} / \mathrm{C}_{2} \mathrm{H}_{5} \mathrm{OH}$<smiles>[R]NC(=S)NNC(=O)CC1(CC)OCCc2c1[nH]c1c(CC)cccc21</smiles><smiles>[R2]n1c(CC2(CC)OCCc3c2[nH]c2c(CC)cccc32)n[nH]c1=S</smiles>

Figure 1. Synthetic route of newly synthesized componds $\mathbf{4 a - h}$.

other aromatic and aliphatic protons for obtained compounds were observed at expected chemical shifts and integral values.

${ }^{13} \mathrm{C}-\mathrm{NMR}$ spectra of compounds exhibited additional signals due to triazole moiety at the expected chemical shift values. The carbon of triazole, $\mathrm{C}=\mathrm{S}$ group and $\mathrm{C}=\mathrm{N}$ group had a typical signals at about $165.49-170.05$ and $149.33-150.04$ ppm, respectively. The peaks resonated at region of $165.49-170.05 \mathrm{ppm}$ in the ${ }^{13} \mathrm{C}$-NMR spectra of these compounds, assigned for $\mathrm{C}=\mathrm{S}$, confirming thione form of triazole ${ }^{28}$. The ${ }^{13} \mathrm{C}$-NMR spectra of the compounds displayed the appropriate number of resonances that exactly assembled the number of carbon atoms. The etodolac derivatives may occur in thione or thiol form. However, in our case the signal of $\mathrm{C}=\mathrm{S}$ group in the ${ }^{13} \mathrm{C}$-NMR spectra and disappearance of $\mathrm{S}-\mathrm{H}$ proton in the ${ }^{1} \mathrm{H}-\mathrm{NMR}$ spectra of etodolac triazoles $(\mathbf{4 a}-\mathbf{h})$ indicated that they were existed in a solution predominantly in thione form. The thione-thiol tautomerism was not observed for etodolac triazoles.

High-resolution mass spectra (HR-MS) confirmed the molecular weights and empirical formulae of the compounds and fragments, with less than $5 \mathrm{mmu}$ bias between the calculated and experimental $\mathrm{m} / \mathrm{z}$ values of either the molecular or the fragment ions. The ionization mode was electron impact (EI) for all triazole derivatives. Etodolac triazoles gave relatively stable molecular ion peaks in the corresponding mass spectra. In addition, the fragmentation pattern for all compounds was supported in the mass spectra. The fragment ion peaks especially $\left[\mathrm{M}-\mathrm{N}_{2}\right]^{+},[\mathrm{M}-\mathrm{HCNS}]^{+},[\mathrm{M}-\mathrm{RNCS}]^{+}$and $[\mathrm{M}-\mathrm{S}]^{+}$are the diagnostic peaks for $1,2,4$-triazoles rings ${ }^{24,29}$. IR, ${ }^{1} \mathrm{H}-\mathrm{NMR},{ }^{13} \mathrm{C}$ NMR and mass spectral data are in agreement with the proposed structures of all newly synthesized compounds.

\section{Biological evaluation}

\section{Anti-cancer activity}

The growth inhibition properties of the compounds selected by NCI, USA, was performed in accordance with the protocol of their Drug Evaluation Branch Selection, and is available online at the DTP web site (http://www.dtp.nci.nih.gov/docs/misc/common_files/guidelines.html) ${ }^{18,30}$. The cytotoxic and/or growth inhibitory effects of the compounds with ethyl and benzyl substituent, $\mathbf{4 b}$ and $\mathbf{4 f}$ chosen as prototypes were tested at a concentration of $10^{-5} \mathrm{M}$ against the full panel of 60 human tumour cell lines derived from nine neoplastic diseases. The percentage of growth was determined spectrophotometrically and compared against DMSO-treated controls. The one-dose assay facilitates detection of both growth inhibition (values between 0 and 100) and lethality (values less than 0). It means that a value of 100 means no growth inhibition. A value of 40 would mean $60 \%$ 
Table 1. The anticancer screening data of etodolac triazoles, $\mathbf{4 b}$ and $\mathbf{4 f}$.

\begin{tabular}{|c|c|c|c|c|c|}
\hline Compound & NCI code & Mean growth \% & $\begin{array}{c}\text { The most sensitive } \\
\text { cell line }\end{array}$ & $\begin{array}{c}\text { Growth } \\
\text { inhibition } \% \text { of the } \\
\text { most sensitive cell line }\end{array}$ & $\begin{array}{c}\text { Growth percent } \% \text { of } \\
\text { the most sensitive } \\
\text { cell line }\end{array}$ \\
\hline $4 b$ & D-753678/1 & 102.49 & $\begin{array}{l}\text { Melanoma } \\
\text { UACC-62 }\end{array}$ & 22.78 & 77.22 \\
\hline \multirow[t]{4}{*}{$4 f$} & D-753679/1 & 77.53 & $\begin{array}{l}\text { CNS cancer } \\
\text { SNB-75 }\end{array}$ & 53.85 & 46.15 \\
\hline & & & $\begin{array}{l}\text { Melanoma } \\
\text { UACC-257 }\end{array}$ & 54.61 & 45.39 \\
\hline & & & $\begin{array}{l}\text { Renal cancer } \\
\text { CAKI-1 }\end{array}$ & 53.51 & 46.49 \\
\hline & & & $\begin{array}{l}\text { Prostate cancer } \\
\text { PC-3 }\end{array}$ & 49.97 & 50.03 \\
\hline
\end{tabular}

growth inhibition. A value of 0 means no net growth over the course of the experiment. A value of -40 would mean $40 \%$ lethality. A value of -100 means all cells are dead. Compounds with cell lines appearing on positive side of mean graph display high growth inhibition of the specific cancer cells. The one-dose data will be described as a mean graph of the percent growth of treated cells. Mean graphs were established for each effect, with bars showing the deviation of individual tumour cell lines from the over all mean value for all the tested cells. In the mean graph, the centre point is the mean of the growth inhibition (GI) percentage over all cell lines. Bars that point to the right are cell lines where the inhibition is greater than the average, while bars that point to the left are cell lines where the inhibition is less than the average. Compounds with cell lines appearing on positive side of mean graph display high growth inhibition of cancer cells of that particular cancer. In Table 1, the results of in vitro anti-cancer screening of $\mathbf{4 b}$ and $\mathbf{4 f}$ are summarized. Tested compounds had moderate growth inhibition effects, which means they had not pass the 5-dose assay. They were unable to reduce the growth of any of the cell lines to $32 \%$ or less.

5-[(1,8-Diethyl-1,3,4,9-tetrahydropyrano[3,4-b]indole-1yl)methyl]-4-benzyl-2,4-dihydro-3 $H$-1,2,4-triazole-3-thione, $\quad$ 4f demonstrated $46.15,45.39,46.49,50.03 \%$ growth percent at $10^{-5} \mathrm{M}$ on CNS cancer SNB-75, melanoma UACC-257, renal cancer CAKI-1, prostate cancer PC-3 cancer cell lines, respectively. Moreover, compound $\mathbf{4 b}$ had a strong cytotoxicity against melanoma MALME-3 $\mathrm{M}$ and compound $\mathbf{4 f}$ had a strong cytotoxicity against melanoma MALME-3 M and leukemia HL-60(TB) cell lines. There are also several reports in the literature on etodolac which were observed to inhibit melanoma by cyclooxygenase inhibitors ${ }^{31}$. Our findings indicated that 1,2,4-triazoles derivatived from etodolac keep going on effect of melanoma.

\section{Anti-HCV NS5B polymerase activity}

Previously synthesized compounds ${ }^{15}$, of etodolac ester (Lab. Code: SGK-196), hydrazide (Lab. Code: SGK-197) etodolac hydrazones (Lab. Code: SGK 198-210), 4-thiazolidinones (Lab. Code: SGK 212-214, SGK 216-221, SGK223) and newly synthesizd compounds of etodolac triazoles $(\mathbf{4 a}-\mathbf{h}$,) were evaluated for their inhibition of hepatitis C virus NS5B RNA dependent RNA polymerase activity ${ }^{32}$. The anti-NS5B polymerase activity of the etodolac 1,2,4-triazoles (Table 2) was investigated in vitro against recombinant NS5BC $\Delta 211 \mathrm{~b}$ by a primer-dependent elongation assay as described previously ${ }^{20,21}$. All compounds were subjected to preliminary screening at $100 \mu \mathrm{M}$ concentration and candidates displaying $\geq 50 \%$ inhibition of NS5B polymerase activity at this concentration were further investigated for their $\mathrm{IC}_{50}$ value. Etodolac, the parent molecule, included in this investigation for comparison, yielded $\sim 10 \%$
Table 2. Anti-HCV NS5B RdRp activity of etodolac derivatives.

\begin{tabular}{|c|c|c|}
\hline Compound (Lab. Code) & $\begin{array}{c}\text { Anti-NS5B } \\
\text { activity }(\% \text { inhibition, } \\
100 \mu \mathrm{M})\end{array}$ & $\mathrm{IC}_{50}(\mu \mathrm{M})$ \\
\hline SGK196 & $6.4 \pm 1.2$ & \\
\hline SGK197 & $11.4 \pm 1.2$ & \\
\hline \multicolumn{3}{|c|}{ Etodolac Hydrazide-Hydrazones } \\
\hline SGK198 & $6.4 \pm 1.3$ & \\
\hline SGK199 & $16.5 \pm 1.8$ & \\
\hline SGK200 & $30.3 \pm 0.2$ & \\
\hline SGK201 & $6.7 \pm 1.0$ & \\
\hline SGK202 & $61.6 \pm 0.4$ & $58.6 \pm 1.4$ \\
\hline SGK203 & $3.4 \pm 0.4$ & \\
\hline SGK204 & $9.2 \pm 0.9$ & \\
\hline SGK205 & $8.4 \pm 1.4$ & \\
\hline SGK206 & $7.1 \pm 0.4$ & \\
\hline SGK207 & $3.6 \pm 1.1$ & \\
\hline SGK208 & $20.0 \pm 0.1$ & \\
\hline SGK209 & $53.7 \pm 0.5$ & $58.6 \pm 1.4$ \\
\hline SGK210 & $45.3 \pm 1.1$ & \\
\hline \multicolumn{3}{|l|}{ Etodolac Triazoles } \\
\hline 4a (SGK238) & $78.9 \pm 0.7$ & $14.8 \pm 1.2$ \\
\hline 4b (SGK239) & $74.6 \pm 1.1$ & $21.6 \pm 1.3$ \\
\hline 4c (SGK240) & $69.0 \pm 0.1$ & $26.0 \pm 1.3$ \\
\hline 4d (SGK241) & $72.3 \pm 0.4$ & $25.4 \pm 1.3$ \\
\hline 4e (SGK243) & $58.2 \pm 0$ & $40.3 \pm 1.2$ \\
\hline 4f (SGK242) & 3.78 & \\
\hline 4g (SGK244) & $49.5 \pm 0.1$ & \\
\hline 4h (SGK315) & 45.6 & \\
\hline \multicolumn{3}{|c|}{ Etodolac 4-Thiazolidinones } \\
\hline SGK211 & 1.80 & \\
\hline SGK212 & 1.01 & \\
\hline SGK213 & 6.66 & \\
\hline SGK214 & 13.22 & \\
\hline SGK216 & $40.3 \pm 0.4$ & \\
\hline SGK217 & NI & \\
\hline SGK218 & 13.1 & \\
\hline SGK219 & NI & \\
\hline SGK220 & 43.2 & \\
\hline SGK221 & 45.2 & \\
\hline SGK223 & 26.3 & \\
\hline
\end{tabular}

NI: no inhibition.

inhibition of NS5B polymerase, while its derivatives displayed $\sim 5.0-80.0 \%$ inhibition of NS5B polymerase activity at this concentration. Of these, all 11 etodolac 4-thiazolidinones proved to be weak NS5B polymerase inhibitors with $\leq 50 \%$ anti-NS5B activity, while two etodolac hydrazide-hydrazones and five etodolac triazoles appeared more promising displaying $\geq 50 \%$ inhibition of NS5B polymerase activity. The triazoles were overall more active than the hydrazide-hydrazones, displaying $\mathrm{IC}_{50}$ values between 14.0 and $26.0 \mu \mathrm{M}$, with the exception of 
Figure 2. Glide-XP predicted binding model of compound $(S)$-4a within the TP-II of HCV NS5B polymerse. Amino acid residues are shown as stick model with the atoms colored as carbon - green, hydrogen - white, nitrogen - blue oxygen - red and sulfur - yellow whereas inhibitor is shown as ball and stick model with the same color scheme as above except carbon atoms are represented in orange. Water molecules are shown as stick model. Dotted black line indicates hydrogen bonding interaction whereas dotted pink line indicates potential electrostatic contact with distances in $\AA$ (please view this figure in color mode in the online version).

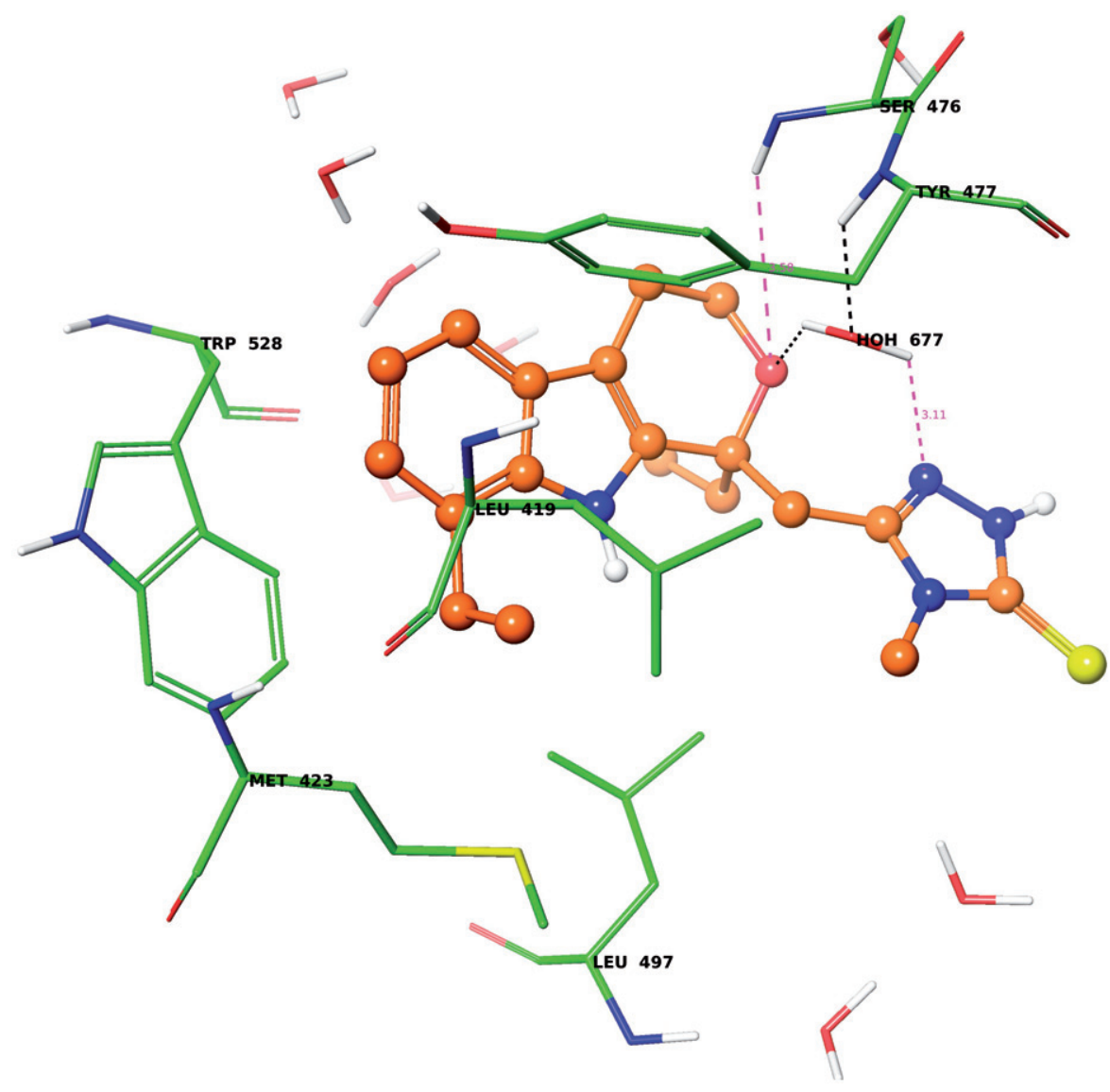

compound 4e $\left(\mathrm{IC}_{50}=40.0 \mu \mathrm{M}\right)$. Among these, compound 4a (SGK 238) with $\mathrm{IC}_{50}$ value of $14.8 \mu \mathrm{M}$ was the most active of the etodolac triazoles. General structure and substituents of etodolac hydrazide hydrazones and etodolac 4-thiazolidinones which were synthesized in our previous study ${ }^{15}$ are given in Supplemental file 2 .

To evaluate the probable binding conformation of the most potent chiral etodolac derivatives, we performed docking study using Glide docking software. Since the structurally related pyranoindoles have been previously shown to inhibit NS5B activity through binding to TP-II, we performed docking calculations at TP-II site ${ }^{13,22}$. Analysis of the binding energy data for the docked conformations of $R$ - versus $S$-isomers of the most active compound of 5-[(1,8-diethyl-1,3,4,9-tetrahydropyrano[3,4$b$ ]indole-1-yl)methyl]-4-methyl-2,4-dihydro-3H-1,2,4-triazole-3thione, 4a (Glidescore for $(R)=-2.94 \mathrm{kcal} / \mathrm{mol}$ and for $(S)=$ $-4.58 \mathrm{kcal} / \mathrm{mol})$, showed that $S$-isomer bind at least by $1 \mathrm{kcal} / \mathrm{mol}$ better than their $R$-counterpart. The binding mode of $(S)$-isomer of the etodolac derivative $4 a$ within the TP-II of HCV NS5B polymerase is shown in Figure 2 (please view this figure in color mode in the online version). The $\mathrm{sp}^{2}$ hybridized nitrogen atom of the triazolethione ring forms a water (HOH677) mediated hydrogen bond with the backbone $-\mathrm{NH}$ of Tyr477 $\left(=\mathrm{N} \cdots \mathrm{H}_{2} \mathrm{O} \cdots \mathrm{HN}-\mathrm{Ty} 477\right)$. The pyran ring oxygen atom also involved in water (HOH677)-mediated hydrogen bonding interaction with the backbone $-\mathrm{NH}$ of $\mathrm{Tyr} 477\left(\mathrm{O} \cdots \mathrm{H}_{2} \mathrm{O} 677 \cdots \mathrm{HN}-\right.$ Tyr477). This pyran ring oxygen atom is also found at electrostatic interacting distance from the backbone -NH of Ser476

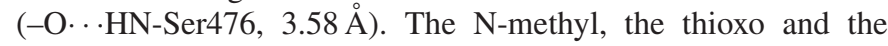
$-\mathrm{NH}$ groups of the triazolethione ring are solvent-exposed. The ethyl substituent on indole nucleus forms hydrophobic interactions with the side chains of Leu419, Met423 and Leu497. The indole nucleus is stabilized by hydrophobic interactions

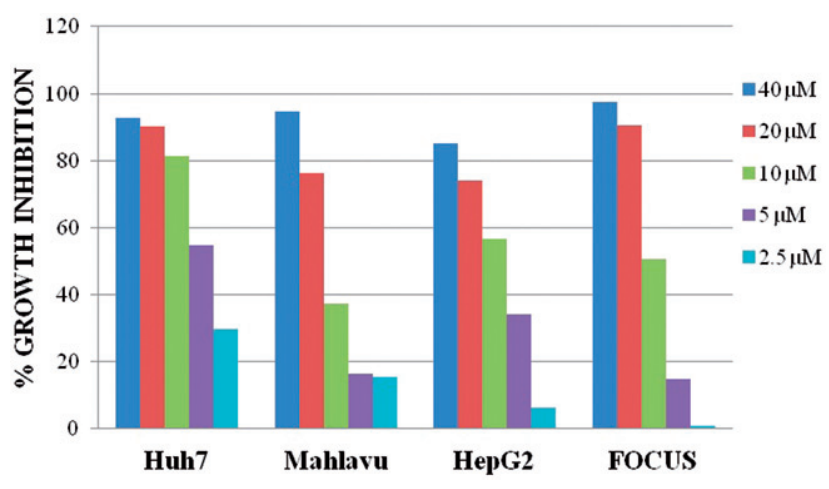

Figure 3. Percent growth inhibition graphs of compound 4a, SGK-238 on liver cancer cell lines (Huh7, Mahlavu, HepG2, FOCUS).

with the side chains of Met423, Tyr477, Leu497 and Trp528. The ethylpyran moiety is mainly stabilized by hydrophobic contacts with the side chain of Tyr477.

The binding mode of $(R)-\mathbf{4 a}$ was found to be completely different and showed no key hydrogen bonding interactions with the residues of TP-II such as Ser476 and Tyr477. Therefore binding energy data and predicted binding conformation together suggest that NS5B inhibitory activity of racemic $\mathbf{4 a}$ could be due to $S$-isomer. Future study will focus on separation of each enantiomer as well as optimization of compound $\mathbf{4 a}$.

\section{Anti-cancer activity of the etodolac triazole, $\mathbf{4 a}$ against human liver cancer cells}

Compound 4a, which exhibited the highest inhibitory activity against HCV NS5B polymerase, was evaluated for its ability to 
Table 3. $\mathrm{IC}_{50}$ values in $\mu \mathrm{M}$ concentrations for compound $4 \mathrm{a}$ with $72 \mathrm{~h}$ of treatment on liver cancer cell lines ${ }^{\mathrm{a}}$.

\begin{tabular}{lc}
\hline Liver cancer cell line & $\mathrm{IC}_{50}(\mu \mathrm{M})$ \\
\hline Huh7 & 4.29 \\
Mahlavu & 10.64 \\
HepG2 & 9.58 \\
FOCUS & 9.78 \\
\hline
\end{tabular}

${ }^{\mathrm{a}} \mathrm{IC}_{50}$ values were calculated from the cell growth inhibition percentages obtained with five different concentrations.

inhibit the growth of liver cancer employing four prototype liver cancer cell lines, Huh7, Mahlavu, HepG2 and FOCUS. Towards this goal, we carried out an anti-cancer drug-screening method based on a sulforhodamine B assay (SRB) in triplicate to determine their $\mathrm{IC}_{50}$ values ${ }^{17}$.

The cells were treated with increased concentration from 2.5 to $40 \mu \mathrm{M}$ of the compound $\mathbf{4 a}$ and incubated for $72 \mathrm{~h}$. Absorbance values were obtained and normalized to DMSO control. The result of anti-cancer analysis of this compound is summarized in Figure 3 . However, the $\mathrm{IC}_{50}$ values were in micromolar concentrations with $\mathbf{4 a}$ against each human liver cancer cells (Table 3). 5-[(1,8-Diethyl-1,3,4,9-tetrahydropyrano[3,4- $b$ ]indole-1-yl)methyl]4-methyl-2,4-dihydro-3H-1,2,4-triazole-3-thione, 4a displayed the best anti-cancer activity, with $\mathrm{IC}_{50}$ value of 4.29 against Huh7 cell line. Considering the anti-cancer activity of this etodolac triazole on the hepatoma cell lines, we further analyzed the cellular activity as a promising candidate anti-cancer agent.

\section{Conclusions}

In the current study, a series of novel etodolac 1,2,4-triazoles were synthesized and evaluated for their anti-cancer activity and inhibition of hepatitis $\mathrm{C}$ virus NS5B RNA dependent RNA polymerase activity. After a preliminary survey, 5-[(1,8-diethyl-1,3,4, 9-tetrahydropyrano[3,4- $b$ ]indole-1-yl)methyl]-4-ethyl-2,4-dihydro-3H-1,2,4-triazole-3-thione, $4 \mathbf{b}$ and 5-[(1,8-diethyl-1,3,4,9tetrahydropyrano[3,4- $b$ ]indole-1-yl)methyl]-4-benzyl-2,4-dihydro-3H-1,2,4-triazole-3-thione, $\mathbf{4 f}$ were selected by the NCI for anti-cancer screening. These etodolac triazoles were found to show significant inhibition on CNS cancer SNB-75, melanoma UACC-257, renal cancer CAKI-1, prostate cancer PC-3 cancer cell lines. In this present study, we have also evaluated inhibition of hepatitis C virus NS5B RNA dependent RNA polymerase activity of etodolac derivatives. Among these, the most active triazole, compound 4a (SGK 238), with methyl substituent displayed $\mathrm{IC}_{50}$ values of $14.8 \mu \mathrm{M}$. Notably, this study reports for the first time the anti-HCV NS5B activity of etodolac 1,2,4triazoles. Molecular docking and binding mode investigations suggest that the 1,2,4-triazole scaffold may be optimized for generating more effective analogues with improved anti-NS5B potency. In order to analyze anti-cancer property of the active compound 4a, anti-cancer assay was investigated on diverse human cancer cell lines. Based on these studies, the $\mathrm{IC}_{50}$ value of compound 4a was analyzed on hepatoma cells. We are now in the process of synthesizing modified analogues of the lead compound in order to generate more effective hepatitis C virus NS5B polymerase inhibitors and candidate anti-cancer agents.

\section{Acknowledgements}

We thank the Division of Cancer Research, National Cancer Institute, Bethesda, MD, for the anti-cancer activity screening. The authors are grateful to Dr. Jürgen Gross from the Institute of Organic Chemistry,
University of Heidelberg, for his generous help on obtaining HR-EI/FAB mass spectra of the synthesized compounds. Etodolac was supplied by Bilim Pharmaceutical Industry Inc.

\section{Declaration of interest}

The authors declare no conflicts of interest. The authors alone are responsible for the content and writing of this article. This work was supported by The Scientific and Technical Research Council of Turkey (TÜBITAK), Research Fund Project Number: SBAG-HYD-339 (108S257) to S.G.K. HCV NS5B inhibtion studies were partly supported by the National Institute of Health Research Grants DK066837 and CA153147 to N.K-B.

\section{References}

1. Hawk ET, Viner JL, Dannenberg A, DuBois RN. COX-2 in cancer a player that's defining the rules. J Natl Cancer Inst 2002;94:545-6.

2. Montalto G, Cervello M, Giannitrapani L, et al. Epidemiology, risk factors, and natural history of hepatocellular carcinoma. Ann N Y Acad Sci 2002;963:13-20.

3. Carr BI. Hepatocellular carcinoma: current management and future trends. Gastroenterology 2004;127:218-24.

4. Koga H, Sakisaka S, Ohishi M, et al. Expression of cyclooxygenase2 in human hepatocellular carcinoma: relevance to tumor dedifferentiation. Hepatology 1999;29:688-96.

5. Küçükgüzel ŞG, Coşkun İ, Aydın S, et al. Synthesis and characterization of celecoxib derivatives as possible anti-inflammatory, analgesic, antioxidant, anticancer and anti-HCV agents. Molecules 2013;18:3595-614.

6. Demerson CA, Humber LG, Abraham NA, et al. Resolution of etodolac and antiinflammatory and prostaglandin synthetase inhibiting properties of the enantiomers. J Med Chem 1983;26:1778-80.

7. Behari J, Zeng G, Otruba W, et al. R-Etodolac decreases betacatenin levels along with survival and proliferation of hepatoma cells. J Hepatol 2007;46:849-57.

8. Liu W, Nakamura H, Tsujimura $\mathrm{T}$, et al. Chemoprevention of spontaneous development of hepatocellular carcinomas in fatty liver Shionogi mice by a cyclooxygenase-2 inhibitor. Cancer Sci 2006;97: 768-73.

9. Cheng J, Imanishi H, Liu W, et al. Involvement of cell cycle regulatory proteins and MAP kinase signaling pathway in growth inhibition and cell cycle arrest by a selective cyclooxygenase 2 inhibitor, etodolac, in human hepatocellular carcinoma cell lines. Cancer Sci 2004;95:666-73.

10. Duran A, Doğan HN, Rollas S. Synthesis and preliminary anticancer activity of new 1,4-dihydro-3-(3-hydroxy-2-naphthyl)-4-substituted5H-1,2,4-triazoline-5-thiones. Il Farmaco 2002;57:559-64.

11. Li Z, Gu Z, Yin K, Zhang R, et al. Synthesis of substituted-phenyl1,2,4-triazol-3-thione analogues with modified D-glucopyranosyl residues and their antiproliferative activities. Eur J Med Chem 2009; 44:4716-20.

12. Gopalsamy A, Lim K, Ciszewski G, et al. Discovery of pyrano[3,4b]indoles as potent and selective HCV NS5B polymerase inhibitors. J Med Chem 2004;47:6603v8.

13. LaPorte MG, Draper TL, Miller LE, et al. The discovery and structure-activity relationships of pyrano[3,4-b]indole based inhibitors of hepatitis C virus NS5B polymerase. Bioorg Med Chem Lett 2010;20:2968-73.

14. Ç1kla P, Arora P, Basu A, et al. etodolac thiosemicarbazides: a novel class of hepatitis C virus NS5B polymerase inhibitors. Marmara Pharm J 2013;17:138-46.

15. Çıkla P, Özsavcı D, Bingöl-Özakpınar Ö, et al. Synthesis, cytotoxicity, and pro-apoptosis activity of etodolac hydrazide derivatives as anticancer agents. Arch Pharm (Weinheim) 2013;346:367-79.

16. Küçükgüzel ŞG, Süzgün P. Synthesis of thiosemicarbazides and triazoles derived from etodolac. Patent WO 2014/003694 A1; 2014.

17. Skehan P, Storeng R, Scudiero D, et al. New colorimetric cytotoxicity assay for anticancer-drug screening. J Natl Cancer Inst 1990;82:1107-12.

18. Grever MR, Schepartz SA, Chabner BA. The National Cancer Institute: cancer drug discovery and development program. Semin Oncol 1992;19:622-38.

19. Weinstein JN, Myers TG, O'Connor PM, et al. An informationintensive approach to the molecular pharmacology of cancer. Science 1997;275:343-9. 
20. Kaushik-Basu N, Bopda-Waffo A, Basu A, et al. 4-Thiazolidinones: a novel class as hepatitis $\mathrm{C}$ virus NS5B polymerase inhibitors. Front Biosci 2008;13:3857-68.

21. Kaushik-Basu N, Bopda-Waffo A, Talele TT, et al. Identification and characterization of coumestans as novel HCV NS5B polymerase inhibitors. Nucleic Acids Res 2008;36:1482-96.

22. Li H, Tatlock J, Linton A, et al. Discovery of (R)-6-cyclopentyl-6(2-(2,6-diethylpyridin-4-yl)ethyl)-3-((5,7-dimethyl-[1,2,4]triazolo [1,5-a]pyrimidin-2-yl) methyl)-4-hydroxy-5,6-dihydropyran-2-ne (PF-00868554) as a potent and orally available hepatitis $\mathrm{C}$ virus polymerase inhibitor. J Med Chem 2009;52:1255-8.

23. Nichols DB, Leão RA, Basu A, et al. Evaluation of coumarin and neoflavone derivatives as HCV NS5B polymerase inhibitors. Chem Biol Drug Des 2013;81:607-14.

24. Küçükgüzel ŞG, Rollas S, Erdeniz H, Kiraz M. Synthesis, characterization and antimicrobial evaluation of ethyl 2-arylhydrazono-3oxobutyrates. Eur J Med Chem 1999;34:153-60.

25. Rollas S, Kalyoncuoğlu N, Sur-Altiner D, Yeğenoğlu Y. 5-(4-Aminophenyl)-4-substituted-2,4-dihydro-3H-1,2,4-triazole-3thiones: synthesis and antibacterial and antifungal activities. Pharmazie 1993;48:308-9.

26. Küçükgüzel İ, Küçükgüzel ŞG, Rollas S, et al. Synthesis of some 3(arylalkylthio)-4-alkyl/aryl-5-(4-aminophenyl)-4H-1,2,4-triazole derivatives and their anticonvulsant activity. Il Farmaco 2004;59: 893-901.
27. Küçükgüzel ŞG, Küçükgüzel I, Tatar E, et al. Synthesis of some novel heterocyclic compounds derived from diflunisal hydrazide as potential anti-infective and anti-inflammatory agents. Eur J Med Chem 2007;42:893-901.

28. Salgın-Gökşen U, Gökhan-Kelekçi N, Göktaş Ö, et al. 1Acylthiosemicarbazides, 1,2,4-triazole-5(4H)-thiones, 1,3,4-thiadiazoles and hydrazones containing 5-methyl-2-benzoxazolinones: synthesis, analgesic-anti-inflammatory and antimicrobial activities. Bioorg Med Chem 2007;15:5738-51.

29. Küçükgüzel I, Tatar E, Küçükgüzel SG, et al. Synthesis of some novel thiourea derivatives obtained from 5[(4-aminophenoxy)methyl]-4-alkyl/aryl-2,4-dihydro-3H-1,2,4-triazole-3-thiones and evaluation as antiviral/anti-HIV and anti-tuberculosis agents. Eur J Med Chem 2008;43: 381-92.

30. Alley MC, Scudiero DA, Monks A, et al. Feasibility of drug screening with panels of human tumor cell lines using a microculture tetrazolium assay. Cancer Res 1988;48: 589-601.

31. Kast RE. Melanoma inhibition by cyclooxygenase inhibitors: role of interleukin-6 suppression, a putative mechanism of action, and clinical implications. Med Oncol 2007;24:1-6.

32. Küçükgüzel ŞG, Süzgün P, Arora P, et al. Etodolac derivatives as HCV NS5B polymerase inhibitors. Patent WO 2014/003693 A1; 2014.

Supplementary material available online. Supplemental file 1 and 2. 